

\title{
Graduate Joblessness: Conviction for Entrepreneurship Studies in Library and Information Science Programme of Nigerian Tertiary Institutions
}

\author{
Atanda, Luqman Ayanlola \\ University Library, Federal University Otuoke, Bayelsa State \\ Email: Atanda@iprjb.org \\ Ugwulebo, Jeremiah Emeka \\ University of Uyo, Uyo, Akwa Ibom State \\ Corresponding Authors Email: Emeka@iprjb.org
}

\begin{abstract}
Purpose: The purpose of the study was to understand what the Nigerian graduates are passing through, most especially graduate of library and information science programme of Nigerian tertiary institutions.

Findings: The statistics of unemployed graduates in Nigeria as at 2011 showed that a disheartening figure of 42.7 million with over 1,8 million graduates churned out of our higher institutions yearly. It was further revealed that the unemployment rate in Nigeria stood at 38 percent in 2013 with further increase expected in succeeding years. The slow rate of economic growth and undeveloped private sector, faulty manpower planning, high expectations of the fresh graduate attitude towards some types of jobs, recruitments, the quest for higher education, inadequate educational curricular, immobility of labour, the long period of initial unemployment among graduates of higher institution, use of capital intensive technology, wide rural-urban migration

Conclusion: It is evident that entrepreneurship education is important for Library and Information Science students in higher institution of learning. The training of Library and Information Science students must reflect the $21^{\text {st }}$ century development in the field which is influenced by the emergence of Information Technology, hence, Library and Information Science students must have computer proficiency, familiarity with metadata, database management and application, web development and design, knowledge of electronic resources and services
\end{abstract}

Keywords: graduate joblessness, entrepreneurship, library and information science, tertiary institution, Nigerian. 


\subsection{Introduction}

There is no contradiction that these are hard times pawn off on the world by global economic downturn. The implications of this have tangible and even sound differently in levels and dimensions across the globe. Africa and particularly Nigeria have had more than a fair share of the consequences of this economic recession resulting in unprecedented soaring of unemployment rates particularly among graduates of higher institutions of learning. Today no discipline is insulated from this precarious trend of graduate unemployment with Library and Information Science inclusive coupled with the fact there has been escalation of Library Schools in Nigeria in the last few decades (JAMB, 2013) which is responsible for the expanding of in-take of fresh Library and Information Science Students at all levels of training in both public and private owned tertiary institutions. The churning out of Library and Information Science graduates from these institutions of higher learning increase the pressure on the available job opportunities in the profession. Though the actual statistics of unemployed Library and Information Science graduates in Nigeria are finding themselves either unemployed, in underpaid school teaching or in dead-end jobs.

Eneji et al. (2013) as quoted in Akinmulegun (2014) presented the Graduates Unemployment Rate in Nigeria between 2003-2011.

Table 1: $\quad$ Graduate Unemployment Rate In Nigeria Between 2003-2011.

\begin{tabular}{|l|l|l|l|}
\hline Year & Rural & Urban & Total \\
\hline 2003 & 8.3 & 17.3 & 25.6 \\
2004 & 12.8 & 25.2 & 38 \\
2005 & 13.3 & 19.0 & 32.3 \\
2006 & 13.4 & 18.8 & 32.2 \\
2007 & 13.4 & 18.7 & 32.1 \\
\hline 2008 & 21.7 & 15.8 & 37.5 \\
\hline 2009 & 19.8 & 19.2 & 39 \\
\hline 2010 & 20.7 & 22.8 & 43.5 \\
\hline 2011 & 25.6 & 17.1 & 42.7 \\
\hline
\end{tabular}

Sources: ILO 2010; the National Bureau of Statistics (NBS 2010-2011).

The statistics of unemployed graduates in Nigeria as at 2011 showed that a disheartening figure of 42.7 million with over 1,8 million graduates churned out of our higher institutions yearly. It was further revealed that the unemployment rate in Nigeria stood at 38 percent in 2013 with further increase expected in succeeding years (This Day, 2015). This revelation is disheartening despite the vast human and material 
resources bestowed on Nigeria. Gross mismanagement, profligatevuspindingg poor leadership and corruption by public officials have not allowed for the optimal utilization of these resources in such a way that would spring maximum economic benefit and employment generation for the citizenry. It is claimed that the worsening employment crisis is partly a reflection of government's inability to design policies that would create jobs or provide enabling environment that would encourage both individuals and private sectors to expand employment opportunities without hindrance.

The sadness of Nigeria's unemployment rate was brought to the fore by the trampling of graduate job seekers to death during the March 2014 Nigerian Immigration Services (NIS) recruitment drive across the country. Economists the world over are unable to agree on the causes of unemployment as there are differing opinions. In Nigeria, the following consensus have been reached as the possible causes of the rising unemployment rate among graduates as reported in a research by Nnadozie, Akwanwa and Nnadozie (2013). According to them, one is the quality of practical and theoretical training to which these employees-to-be were exposed. This is exacerbated by the global economic melt-down which has constrained the ability of the public and private sectors to employ and retain librarians and other categories of library workers. Experts have also hinted at a possible mismatch between the type of education received in Nigeria's tertiary institutions and the actual needs of industries and other employers of labour (Obisesan, 2010 and Ekere and Ekere, 2012). The third and perhaps, most poignant factors is the general orthodox orientation of Nigerian graduates, including library professionals, to depend on paid employment upon graduation rather than use their training and exposure to create jobs and allied economically-viable businesses. Available literature revealed further causes of graduate unemployment as follows:

The slow rate of economic growth and undeveloped private sector, faulty manpower planning, high expectations of the fresh graduate attitude towards some types of jobs, recruitments, the quest for higher education, inadequate educational curricular, immobility of labour, the long period of initial unemployment among graduates of higher institution, use of capital intensive technology, wide ruralurban migration (Oluseyi and Elegbede, 2012).

The above simply suggest that increasing rate of unemployment can be attributed to the dwindling revenue of government which has considerably reduced their capacity to serve as the major source of white collar jobs. There is also the issue of inadequate training received by graduate which make them unemployable even when jobs are there.

It was in response to the need to curb the high rate of graduate unemployment in Nigeria, that the Federal Government introduced entrepreneurship education into the curricula of higher education in the country. The expectation is that the programme will pave the way for graduate entrepreneur who own and run their own businesses and in so doing, create employment opportunities for others. 
The concept of entrepreneurship has a wide range of meanings as several scholars have defined the term. However, there seem to be no universally accepted definition as it is seen from the view point of economics, psychology, anthropology, sociology or management thinkers and scholars. It is safe to say that entrepreneurship has a multidimensional meaning taking a cue from Shane and Venkataraman (2000) who posited that it involves entrepreneurial individuals seizing and exploiting lucrative opportunities. It includes the study of sources of opportunities; the process of discoveries, evolution and exploitation of opportunities and the set of individuals who discover, evaluate and exploit them. Entrepreneurship is simply the set of attributes that an entrepreneur possesses and the practices to establish and run a enterprise. It encompasses decision making, innovation, implementation, forecasting of the future, independence etc. It is a dynamic process that involves the fusion of capital, technology and human talent as demonstrated by the integrated definition given by Kuratko and Hodgetts (2007) that Entrepreneurship is a dynamic process of vision, change and creation. It requires an application of energy and the passion towards the creation and implementation of new ideas and creative solutions. Essential ingredients include the willingness to take calculated risks-in terms of time, equity or career, ability to formulate an effective venture team; the creative skill to marshal the needed resources; the functional skill of building a solid business plan and family, the vision to recognize opportunity where others see chaos, contradiction and confusion. It is also seen as a set of attribute that an entrepreneur possesses and practices to establish and run the enterprise which is supported by Enikanselu as quoted by Nwosu (2014) that perceive entrepreneurship as people who have the who have the ability and advance business opportunity, gather the necessary resources to take advantage of them and to initiate appropriate actions to ensure success. In the same vein, Drucker (1985) as quoted by Nuade (2013) defined entrepreneurship as a systematic innovation which consist in purposeful and organized search for changes and the systematic analysis of the opportunities such changes might offer for economic and social innovation. Nwosu (2014) gave the following general conceptions of entrepreneurship:

$\checkmark$ Entrepreneurship as a function of innovativeness.

$\checkmark$ Entrepreneurship as a function of high achievement.

$\checkmark$ Entrepreneurship as function of management skill and leadership.

$\checkmark$ Entrepreneurship as an organization building function.

$\checkmark$ Entrepreneurship as function of social, political and economic structure.

\subsection{Theoretical Perspectives on Entrepreneurship}

Just as there is no generally accepted concept of entrepreneurship, there is no generally accepted theory of entrepreneurship based on the multidisciplinary nature of the field. However, this paper will be based the Joseph Schumpater's Innovation theory and Gilder's economic survival theory as reported by Nwosu (2014).

\subsubsection{Innovation Theory of Entrepreneurship}

This theory is built on the premise that an entrepreneur must have three major characteristics; innovation, foresight, and creativity. Entrepreneurship takes place when the entrepreneur: 
$\checkmark$ Creates a new product. www.iprjb.org

Introduces a new way to make a product.

$\checkmark$ Discovers a new market for a product.

$\checkmark$ Finds a new source of raw material.

$\checkmark$ Finds new way of making things or organization.

It follows the view that economic development occurs through a dynamic process of boom and depression (business circle) and thus a high supply of entrepreneurship is a function of the rate of profit and the social climate. A vibrant profitable economy encourages entrepreneurship while a depressed economy discourages entrepreneurship. The social climate includes the educational system, the social values, the class structure, the nature and extent of prestige and other rewards that accompany business success and the attitude of the society towards business success.

This theory is related to the study because it is hinged on innovation, foresight and creativity and that is the basis for justifying entrepreneurship education in library and information science. Our educational system must support innovation and creativity since it is revealed that economic development is the function of profits and social climate. By this theory, a pragmatic philosophy of education that is qualitative and purposeful, that encourages skill acquisition; self-reliance and self-employment is key to improving the pool of entrepreneurship.

\subsubsection{Economic Survival Theory}

This theory is often referred to as the movement from poverty to wealth (Gilder, 1981). The theory assumes that entrepreneurship is more prevalent among people who are oppressed by marginalization; suppressed by discrimination; victimized by circumstances and affected by political upheaval. It is believed that people who are faced with the above challenges channel their creative abilities to entrepreneurship.This theory related to this study because of the precarious trend of graduate unemployment in Nigeria which has assumed a disheartening proportion. There is the need to create in students the need to strive for survival through entrepreneurship education.

\subsection{ENTREPRENEURAL EDUCATION}

The whole concept and theory of entrepreneurship centred on individual in-born characteristics which informed the debate among researchers if entrepreneurial skills and competencies can be acquired in a formal school setting. Peter Druker (1985) as quoted by Nnadozie (2014) gave credence to entrepreneurship education stating that entrepreneurship is no mystique and magic and has nothing to do with the genes. It is a discipline and like any other discipline, it can be learned. In a similar view, McMillan (2006) described entrepreneurship education as a type of learning directed towards developing in young people those skills, competencies, understandings and attributes which equipe them to be innovative, and to identify, create, initiate and successfully mange personal, community, business and work opportunities. Also, Nwosu and Ohia (2009) posited that entrepreneurship education is that aspect of formal learning which equips an individual and creates in the person the mindset to undertake risk of venturing into something new by applying the knowledge and skills acquired in school.

From the foregoing, it could be seen that entrepreneurship education is a carefully planned academic programme designed to provide the learner with specialized skills, as well as the encouragement and motivation to creativity apply such knowledge to viable economic activities. 


\subsection{Entrepreneural Education in Library and Information Scieneenw.iprjb.org}

Entrepreneurship education would make Library and Information Science graduates better positioned to identify and harness the innovative opportunities that abound within and outside the profession. Opportunity refers to the possibility of putting available or existing resources to good use in order to achieve given ends. They are seen as positive external options that an individual exploit to accomplish his/her mission goals and objectives (Akanwa, Anyanwu \& Ossai-Onah, 2014). Entrepreneurial opportunities can either be innovative or exploitative. While the former involves the process of creating new profitable products and ideas by incorporating observations and insights gotten from new profitable products and ideas by incorporating observations and insights gotten from elsewhere, the latter is the ability to discover an unexploited market through information available hinged on great insight and analytical mind. The teaching of entrepreneurship education to Library and Information Science students would equip them with the capacity and capability to discover both the innovative and profitable opportunities inherent in the profession.

Opportunities (change oriented, decision-based, value-oriented, peculiarity, re-creative in nature, requires skills, recognisability) abound in the Library and Information Science profession and it is only through entrepreneurship education that such opportunities can be effectively harnessed for economic viability (Akanwa, Ayanwu and Ossai-Onah, 2014).

Entrepreneurship education in Library and Information Science would be a potent instrument capable of unleashing the economic potentials of students thus leading to the discovery of entrepreneurial opportunities in Library and Information Science especially in the following broad areas as given by Issa, Uzuegbu and Nwosu (2014):

$\checkmark$ Library equipment business.

$\checkmark$ Book shops/ book sales

$\checkmark$ Printing and publishing business

$\checkmark$ Information brokerage/researcher.

$\checkmark$ Courier services business.

$\checkmark$ Library consultancy business.

$\checkmark$ Stationery business.

$\checkmark$ Reprographic business.

$\checkmark$ Art gallery business.

$\checkmark$ Information communication and technology based business.

And a host of others because of the evolving nature of discipline.

All the mentioned above equally have sub-business areas which the Library and Information Science graduates can venture in and make a good living thereof.

For a full treatment of the above business areas, see Issa, Uzuegbu and Nwosu (2014). Entrepreneurship Studies and Practices in Library and Information Science. 


\subsection{Conviction for Entrepreneurship Education in Library and Infowmation science}

The major reason for the existence of entrepreneurship education is the need to create more willing and competent entrepreneurs. The need to broaden the skills and knowledge base of the products of various educational institutions is equally key to the introduction of entrepreneurship education as the skill-gap and other deficiencies noticeable in graduates of tertiary institutions in Nigeria have assumed an embarrassing proportion. This informs the concern expressed by various stakeholders especially employers of labour over the poor quality of education. The idea is to enrich the learning experiences as well as expose the learner to business management skills, risk bearing, fund-raising and another element of positive work ethics.

Any discussion on the rationale for entrepreneurship education will be incomplete without the desire to reduce the burgeoning unemployment among graduates as it has attained a worrisome dimension. Consequently, it has become a matter of necessity to draw the attention of graduates to entrepreneurial opportunities and more importantly impart into them business skills and strategies corporate strategies (Nnadozie, Akanwa \& Nnadozie, 2013).

The foregoing assertion is true of the need for entrepreneurship education in Library and Information Science as it would inculcate into the students the skill or expertise to explore opportunities in other sectors where they can put their specialized training to their best advantage. The justification for entrepreneurship education in Library and Information Science graduates in Nigeria are finding themselves either unemployed, in underpaid school teaching or in deed-end jobs.

Several studies have shown that entrepreneurship education is a key in creating innovation, wealth and employment as it is a known fact the corporate organization and various government agencies would deliberately engage people who would use their talent to bring about innovation and add value to their corporate existence. Adeogun (2006) as quoted in Nnadozie, Akanwa \& Nnadozie (2013) in the same vein asserted that the most valued skill is the ability to access, synthesize and build information into new knowledge. This capacity to access, synthesize and build information into new knowledge should be a major focus of entrepreneurship education. Thus the rationale for entrepreneurship education in Library and Information Science is equally geared towards creating entrepreneurs and intrapreneurs i.e. employable justification for entrepreneurship education as follows:

To boost professional status: The library and information profession though still evolving in Nigeria can earn respect and recognition accorded to other profession when Library and Information Science graduates become entrepreneurs who own information outfits in the society making comparable impact on the people with those of other profession. Entrepreneurship in Library and Information Science will boost professional recognition and status as stated by Aina (2007) when he commented as follows:

A professional will be respected in a society, if there is assurance that trainees in the profession would easily find jobs after graduation. However, a profession will go into oblivion, if after graduation, its graduates are unable to secure employment in the private and public sectors or they are unable to create self-employment..... this is why many professions ensure that their trainees are exposed to an appropriate curriculum that would provide the society the required skills. 
The diversification of job market for Library and InformationibScience Graduates: The imperative of a diversified job market owes to the nature of traditional library job which imposes limitation on access to jobs by librarians. The nature of library job market are of three dimension, firstly, Nwosu (2011) in Nwosu (2013) reported that there are 7,237 undergraduates in twenty Library and Information Science schools for four years beginning at the end of 2010/2011 academic session. The above is exclusive of those whose first professional qualification is the Master of Library and Information Science. Similarly, there are 1,032 libraries in Nigeria as the current National Library of Nigeria (2011) Mailing List of Libraries in Nigeria suggests. The above is simply an indication that the production level of Library and Information Science schools is quite high and the librarians' job market is limited in scope as the libraries cannot absorb all the graduates from library schools. Secondly, library jobs falls into the public service domain which is controlled by the government of which government policies and regulation are overriding. Therefore, government restrictions or total ban on employment imposes a barrier on engagement of qualified librarians even when the vacancies are there as it was the case in Imo State Civil Services during the military regime until 2010 (Obi, 2010). Conclusively, the traditional library job market insensitive to the individuality of librarians. A mono job market for all librarians fails to recognize the personal preference of individual librarians. Certain individuals may be trained as librarians but may not be attracted to a job in the traditional library environment that is largely routine or monotonous in a serene environment. In a mono market system, such people will either accept a job in the library or be condemned to a career life time of drudgery or they decline from the profession. When librarians are equipped with the right skills, they can pursue a career in the information profession as private practitioners hence it is urgent and imperative for a paradigm shift from a mono job market in a traditional library to a multi job market.

$\checkmark$ To promote efficiency in the Library: The introduction of entrepreneurship education in Library and Information Science will promote efficiency in the library as the traditional library services can be improved with the fusion of entrepreneurial ideas. Riddle (2003) affirmed that librarians can adopt techniques and tools in the business sector to improve library efficiency while not compromising their public services mission. It should be noted that the traditional library still remains the base of the Library and Information Science profession and therefore whatever tends to the improvement of its operational efficiency must not only be encouraged but vigorously pursued. Though entrepreneurship education, the librarians imbibe the entrepreneur's principle of "customer satisfaction" which drives altruism in service delivery.

$\checkmark$ To demonstrate conformity with Government policy: Entrepreneurship education was introduced into the Nigeria University system in 2007 by the Nigerian government acting through the Nigerian University Commission (NUC) to curb the spate of unemployment among the teeming graduates of Nigeria universities. The sole objectives of this is to imbue students with the right skills and attitude towards job creation. In furtherance to the above, embroidering the library and information science programme with entrepreneurship education is congruent with government policy.

\subsection{Constraints to Entrepreneurship Education in Library and Information Science}


There are impediments to the realization of the benefits of entrepremandip.edgcation with particular reference to Library and Information Science. Some of these challenges are discussed below:

Entrepreneurship education is taught in the Nigerian tertiary institutions as a general course and perhaps does not allow for in-depth treatment of topics with particular reference to the peculiarities of individual disciplines. As a consequence, the present entrepreneurship education does not allow for Library and Information Science students to explore the rich and vast business opportunities inherent in the profession. Notwithstanding that the course is domiciled under the school of General Studies, the time allotted to the course is usually insufficient, course content treatment highly theoretical and tools/ facilities for practical sessions are lacking. Besides, interface with successful firms and industries are non-existent. This situation contrasts with focus of entrepreneurship education which must have a good mixture of theory and practice and must involve the larger community outside the tertiary institutions. The external community is rich resources for the development and impartation of knowledge of entrepreneurship because it hosts the business and industrial concerns at which students can be posted to acquire experience on how to run a successful business organization (Nnadozie, 2014).

Similarly, there is a dearth of entrepreneurship education lectures/resource persons to impart with particular reference to Library and Information Science. The programme, as presently packaged, cannot be successful and beneficial to the students when most people given the task to impart entrepreneurial knowledge are inadequately trained and lacking in practical experience in entrepreneurial activities. More so, the curriculum of Library and Information Science in Nigeria higher institution does not totally reflect the multidisciplinary nature of the discipline. The shortcomings of Library and Information Science curriculum constraints the ability of their products to initiate and successfully manage business ventures (Nnadozie, 2013). This challenge has been reported in succession by library scholars (Adimorah, 2002; Nnadozie, Akanwa \& Nnadozie, 2013; and Nwosu, 2013 ). Nnadozie (2013) further revealed that part of the shortcomings was due to the largely bookish, theoretical, civil service oriented nature of Library and Information Science curriculum which lack the philosophy of self-reliance.

Furthermore, the Student Industrial Work Experience Scheme (SIWES) in Library and Information Science does not reflect and engender entrepreneurship as students are confined to the traditional library rather than seek experiences in other information related business enterprises that will expose them to greater insight towards self-reliance.Conclusively, students are yet to fully grasp the importance of entrepreneurship education as a tool for economic empowerment, wealth and employment generation as they merely see it as a compulsory requirement for graduation. This could be attributed to the inadequacies of the course content. Learning support facilities, curriculum, funding and resource persons which have made the course less attractive to the students. Therefore, these students do not see it as a vital tool for creating innovation and exploiting opportunities for both personal and community development. Students have not realized or pretend not to realize the challenge of graduate unemployment staring them in the face. The lack of interest in entrepreneurship education on the parts of students undermines its effectiveness and inhibits the benefits therein.

\subsection{Conclusion}

It is evident that entrepreneurship education is important for Library and Information Science students in higher institution of learning. The training of Library and Information Science students must reflect the 
$21^{\text {st }}$ century development in the field which is influenced by the emengencipridf.dmgormation Technology, hence, Library and Information Science students must have computer proficiency, familiarity with metadata, database management and application, web development and design, knowledge of electronic resources and services etc. These competencies are relevant as the portfolio for librarians are changing drastically as librarians are now digital librarian, system analyst, data administrator, metadata analyst, web archivist, library consultant, web services librarian, metadata librarian, data officer, knowledge specialist, business researcher, researcher, document control specialist, information analyst, web developer, information architect etc. Thanks to the rise of modern technology. Computers, social media, and other tools have all made it much easier for librarians to perform their duties. The digital age has transformed hoe information is accessed and retrieved. The library is now a part of a complex and dynamic educational, recreational, and informational infrastructure. Librarians in training need to be proactive, pragmatic, resourceful and $21^{\text {st }}$ century compliant.

It should also be noted that improving the quality of entrepreneurial ability means not only improving the skills and education of students " their human capital" but focusing on their innovative abilities. It is innovative entrepreneurship that is most desirable for growth. The central focus of our entrepreneurship education should be geared towards innovation because it is innovation policy that will engender entrepreneurship promotion in our developing economy as it has been in developing economies.

\subsection{References}

Adeogun, M. (2006). The challenges of modern tertiary education system: Paradigm for

Educators and Information Professionals in Sub-Saharan Africa. African Journal of Library, Archives and Information Science, 16(1), 46-48.

Aina, L.O. (2007). Appropriate curriculum for library and information science schools in

Nigeria: the role of Nigerian Library Association. In: Nigerian Libraries for the Future: Progress, Development and Partnerships: paper Presented at the $45^{\text {th }}$ National Conference and Annual General Meeting of the Nigerian Library Association, Uyo, 2007. Ibadan: HEBN Publishers.

Akanwa, P.C.; Anyanwu, E.U.; and Ossai-Onah, O.V. (2014). Entrepreneurial opportunities in the library and information profession. In Issa, A.O.; Uzuegbu, C.P.; and Nwosu, M.C. (eds) Entrepreneurship Studies and Practices in Library and Information Science. Lagos: Waltodany Visual Concept.

Akinmulegun, S.O. (2014). Unemployment and poverty paradigm in Nigeria: challenges and prospect. International Journal of Management and Administrative Science, 2(3), 16-23.

Chima, O. (2015). Nigeria's unemployment rate may rise by 2\%. This Day, March 2, 2015.

Accessed from http://www.thisdaylive.com

Ekere, F.C.; and Ekere, N. (2012). Exploring the potentials of information brokering in Nigeria as an alternative career to librarianship. In: L.O. Aina and I. Mabawonku (eds), Nigerian Library Association at 50: promoting Library and Information Science Profession for National Development and Transformation. Compendium of Paper Presented at the 2012 AGM/Conference of NLA, July. 
Issa, A,O,; Igwe, K.N., and Ugwuogu, U.O. (2014). Business information.iphighaoygcompetencies

for entrepreneurs. In Issa, A.O.; Uzuegbu, C.P. and Nwosu, M.C. (eds), Entrepreneurship Studies and Practices in Library and Information Science. Lagos: Waltodany Visual Concept.

JAMB (2013). 2013 Unified tertiary matriculation examination (UTME). Abuja: Joint Admissions and Matriculation Board (JAMB).

Kirzner, I.M. (1984). The role of entrepreneur in the economic development system. Retrieved from http://www.CIS.org.au/Events/JBL/jol84.htm

Kirzner, I.M. (1999). Entrepreneurial Discovery and the Competitive Market Places: An Australian Approach. Journal of Economic Literature, 35, 60-85.

Mbaegbu, D.G.E. (2008). Entrepreneurship development theories: An overview and critique.

Proceedings of the first Chike Okoli International Conference on Entrepreneurship, Titled "Entrepreneurship and Africa's Quest for Development". Published by Chike Okoli Centre for Entrepreneurial Studies, Nnamdi Azikwe University, Awka, Nigeria.

McMillan, A. (2006). Teach yourself entrepreneurship. Abington: McGraw-Hill.

Nnadozie, C.O.; Akanwa, P.C.; and Nnadozie, C.D. (2013). Impact of entrepreneurship

education on the career aspiration of Nigeria para-professional librarians-in-training. Academic Journal of Interdisciplinary Studies, 2(5), 149-161.

Nnadozie, C.O. (2013). Entrepreneurial librarianship in Nigeria: Rationale, opportunities and challenges. Nigerian Libraries, 46(2), 11-32.

Nnadozie, C.O. (2014). The Concept of Entrepreneurship Education: Justification for its

Teaching and Learning in Library and Information Science. In Issa, A.O.; Uzuegbu, C.P. and Nwosu, M.C. (eds) Entrepreneurship Studies and Practices in Library and Information Science. Lagos: Waltodamy Visual Concept.

Nwosu, B. And Ohia, A. (2009). Managing entrepreneurship education at the tertiary level in

Nigeria. A panacea for graduate self-employment. African Journal of Education Research and Development, 3(2), 49-53.

Nwosu, C.C. (2014). Entrepreneurship Training in Library and Information Science Education in

Nigeria: Imperatives and Challenges. Middle belt Journal of Library and Information, 11(1), 134144.

Nwosu, M.C. (2014). Introduction to Entrepreneurship. In Issa, A.O.; Uzuegbu, C.P. and Nwosu,

M.c. (eds) Entrepreneurship Studies and Practices in Library and Information Science. Lagos: Waltodamy Visual Concept.

Obi, I. (2010). My reflection on 10,000 jobs offer for Imo Youths. Available at naijahotjobs.com Accessed 16 January, 2012.

Obisesan, M. (2010). Appointment and Management: Pay Attention to Entrepremeurial Skills. 
International Journal of Sociology

Vol 4, Issue 1, No.3, pp. 52 - 63, 2020

Riddle, J. (2003). Developing Business and Management Skill for the $21^{\text {st }}$ Century Academic

Librarian. In: Bridges, K. (eds) Expectations of Librarians in the $21^{\text {st }}$ Century. London: Greenwood, 124-131.

Shadare, O.L. and Elegbede, S.T. (2012). Graduate Unemployment in Nigeria: Causes, Effects and Remedies. British Journal of Arts and Social Sciences, 5(2), 142-154.

Shane, S.A. and Venkataraman, S. (2000). The Promise of Entrepreneurship as a Field of Research. Academy of Management Review, 25(1), 217-226.

Wim, N. (2013). Entrepreneurship and Economic Development Theory, Evidence and Policy. The Institute for the study of labor (IZA), Discussion Paper No. 7507. 